\title{
ROLE OF TEACHING STYLES ON SELF- REGULATION AMONG THE ADOLESCENTS WITH PHYSICAL DISABILITIES
}

\section{Touseef Khalid $^{1 *}$, Iffat Rohail ${ }^{2}$, Andleeb Akhtar ${ }^{3}$}

${ }^{1 *}$ Ph.D., Scholar, Department of Psychology, Foundation University, Islamabad, Pakistan, and Senior Special Education

Teacher, Special Education Department, Rawalpindi, Pakistan; ${ }^{2}$ Professor, Department of Psychology, Foundation

University, Islamabad, Pakistan; ${ }^{3}$ Lecturer Psychology, The University of Haripur, Haripur, Pakistan, and Ph.D., Scholar,

Department of Psychology, Foundation University, Islamabad, Pakistan.

Email: ${ }^{1 *}$ touseef.09@gmail.com, ${ }^{2}$ iffat.rohail@ fui.edu.pk, ${ }^{3}$ andleebmalik81@yahoo.com

\section{Article History: Received on $15^{\text {th }}$ April 2021, Revised on $25^{\text {th }}$ April 2021, Published on $1^{\text {st }}$ May 2021}

\begin{abstract}
Purpose of the study: This study examined the role of teaching styles on self-regulation among adolescents with physical disabilities and moderating effects of age on the relationship between teaching styles and self-regulation.

Methodology: 150 students from Islamabad and Rawalpindi divisions were included in this study. Adolescent SelfRegulatory Inventory (Moilanen,2007) and Junior High School Teaching Styles Questionnaire (Chen,2008) was used to assess teaching styles and self-regulation. A purposive-convenient sampling technique was used, and SPSS 22 was used for data analysis.
\end{abstract}

Main Findings: The results demonstrated that the democratic teaching style was the most perceived teaching style among adolescents with a physical disability. It was found that teaching styles predicts self-regulation significantly with $\left(\beta=.24, \mathrm{R}^{2}\right.$ $=.05)$ and $p<.001$. Democratic teaching style had a significant relationship with long-term self-regulation. Age played a moderator role between teaching style and self-regulation with $\left(\beta=-.16, \mathrm{R}^{2}=.09\right)$ and $p<.01$ among adolescents with a physical disability.

Applications of this study: Results of the study will be helpful in the rehabilitation of this marginalized part of society and helps teachers to understand that how their style could affect the personality development of special students.

Novelty/Originality of this study: There is a need to study the handicapped population, their problems, and opportunities for their rehabilitation, especially in Pakistan. As the needs of students with disabilities are entirely different from regular students, society and teachers need a constructive mindset to solve and eliminate the challenges faced by them.

Keywords: Teaching Style, Self-Regulation, Democratic Teaching Style, Physical Disability, Age.

\section{INTRODUCTION}

Teachers teaching methodologies used during the course of study have a strong effect on the quality of learning and acquisition of skills by students. The utilization of different teaching methodologies by teachers in the classroom is a teaching style. The behaviour's shown by the teacher in the classroom while teaching is called teaching style (Genc \& OganBekiroglu, 2004). Highly professional teachers can change monotonous lessons in motivating one through unique teaching techniques (Umer \& Siddique, 2013). According to Conti (2004), teacher's philosophy associated with teaching is their teaching style. Teachers' belief system, social and cultural norms, personality characteristics, personal objectives and experiences can influence their philosophy of teaching. It is essentially a "teaching style" which influences students and have a prominent impact on the students' performance. According to Elsevier (2012), education is strongly affected by motivational methods and the instructor's teaching style, so the right teaching style may be constructive in optimizing student success. Traditionally, teachers are often viewed by students as providers of information. But now, teachers are required to play a new major role as a facilitator in facilitating the learning process for students and improving multiple intelligence and lifelong learning skills of students. The teaching and learning process has spread through borders of the world due to rapid changes in teaching methods (Gupta \& Bashir, 2017).

Self-regulation is one's capacity to change behaviour (Baumeister \& Vohs, 2007). Zimmerman and Kitsantas (2005) noted that self-regulation is aiming for social acceptance. It is a capability required for activation, inhibition, preservation, and adaptation of behaviour, cognition, emotions, and attention flexibly. It helps not only to respond to internal but external stimuli and clues and provide feedback regarding goal achievements that are relevant personally (Moilanen, 2007; Demetriou, 2005; Novak \& Clayton, 2001). It helps an individual to adjust to demands of societal and situational elements which are encountered in everyday life (Baumeister \& Vohs, 2007). It has highlighted the social ethics and conscience of an individual upon selfish impulses and gives a better understanding of what is right and what is wrong (Baumeister \& Bushman, 2008). It helps adolescence to function in society as an autonomous individuals (Peckham et al., 2001). A key highlight of independence is the capacity to form suitable choices. A person who is self-regulated targets achievable objectives and reasonable activities to achieve these objectives and utilizing their assets, and be careful of their confinement 
(Miller \& Byrnes, 2001). As self-regulation is about planning, adopt and evaluating. Fuente et al. (2018) stated that this process gives flexibility and enhances abilities to make corrections with the change in the learning situation. Self-regulation helps students to monitor their mistakes and learning (Callan \& Cleary, 2018; Zheng et al., 2020). Effective teaching is about not only good teaching practices but fostering certain qualities like control over some instincts. Innovation in teaching styles must be designed to raise the level of self-regulation and reduce the level of stress (Paris \& Winograd, 2003; Putwain et al., 2019; Shannon et al., 2019).

Awareness about teaching style impacts on the teacher-student interactions, activities assessment, and classroom settings, provides information to better understand, change, modify and support though maintain contextual teaching aspects and improve their interaction with pupils. Because of this difference among teaching-learning styles, some teachers recommended that getting further information about the interaction between teaching and learning styles may lessen the incongruence of learning in any classroom (Alhussain, 2012; Lage et al., 2000; Vermunt \& Verloop, 1999). It was also studied that a higher chance of learning and success is associated with pupil-centred (learner teaching style) as compare to content-centred or management teaching style (Opdenakker \& Damme, 2006). Chang (2010) also supported the importance of a suitable teaching style that results in high academic performance. The democratic style is more suitable as compared to the authoritative style. It positively affects learners to motivate and participate, increases team spirit and communication, mutual respect, and trust based on a relaxed environment (Peacock et al., 2012).

Students could perform academically better when they feel that though their teachers have established some rules for them, at the same time, they will also listen to their problems and opinion as well (Chen, 2008). Suitable teaching and students' trust in teachers can enrich their creativity, engagement, and performance. In a student-teacher relationship, the teacher should be a motivation (Pachler et al., 2018). Hussain and Ayub (2012) also suggested that sessions must be planned for teachers to understand the importance and awareness about their teaching styles.

Recent research regarding Student-Teacher Relation (STR) has suggested that the quality of STR plays a significant part in building self-regulation and academic skills (Cadima et al., 2015; Berry, 2012). It is found that healthy relationships between students and teachers are the result of warmth, closure, and support. Low levels of conflict provide emotional security to students, which builds self-regulation skills (Cadima et al., 2015; Rudasill \& Kaufman, 2009; Baker, 2006; Pianta, 1999). Cadima et al. (2015) revealed that teachers who are cooperative and supportive appeared as good predictors of preschoolers' self-regulation. Some other research showed that intelligent students with good self-regulation skills perform well in math and reading skills due to the positive relationship between students and teachers (McTigue et al., 2008).

Teachers working with special students need teaching training to teach them, which is challenging in terms of skills and knowledge (Sharma et al., 2020) because these students have limited skills and intelligence, their parents and teachers need to train them by extra struggle (Mamta et al., 2020). Teachers in the special education field should choose this profession carefully; their sensitivity toward disability could impact positively their teaching skills and quality (Neeraj et al., 2020). Training and feedback about different teaching styles could improve students' interest in learning and creativity (Zhao and Chen, 2016).

The educational psychologist believed that student's learning depends on self-regulation, which keeps them motivated and active to learn. Mega et al. (2014) also suggested that students with successful self-regulation participate in the learning process actively as it has a strong impact on their motivation, meta-cognition, and behaviour. Self-regulation also has a strong correlation with high school performance and adjustments skills (Canzana, 2012), and poor self-regulatory behaviour has positively related to underachievement (Daniela, 2005). This process not only helps the individual to deal with adverse situations in life and activate the maximum level of functioning but also states dysfunctions. It significantly predicts positive adjustment in university students who score less on psychopathological symptoms, e.g. depression, stress, and anxiety, and high on self-esteem, identity, good interpersonal skills, and psychological wellbeing. Self-regulatory skills were found to be beneficial in stress management and strengthening self-control among students (Wayment \& Cavolo, 2019; Fomina et al., 2020; Fuente et al., 2020).

Murray and Rosenbalm (2017) suggested that adolescent should learn these skills in this period, e.g. sticking on difficult and complex long term tasks, regulate behaviour for future goals, making decisions, developing problem-solving behaviour, learn to delay gratifications, self-rewarding and self-monitoring practices, broadening perspectives related to self and others, managing stress and frustrations effectively, and looking for help in an unmanageable situation. Children are not able to cope with the negative behaviour of others, especially rejection by friends due to poor self-regularity skills. They could not get social and emotional stability (Bishep, 2006). They remain unable to enjoy psychological wellbeing and lost control to strive with mild psychopathologies (Hoylee, 2006). Thus it plays a major role in adaptive and effective functioning.

Education and age are protective factors for people who have to live with a disability. Therefore, teachers should be alert about improving their performance and choosing the most suitable teaching style. Alhussain (2012) proposed that teachers 
should be encouraged to choose mixed styles in order to meet diverse learning needs according to their ease. Teachers might find their students to respond better if they themselves can explore other suitable teaching styles.

\section{Significance of Study}

There is a need to study the handicapped population, their problems, and opportunities for their rehabilitation, especially in Pakistan. As the needs of students with disabilities are entirely different from regular students, society and teachers need a constructive mindset to solve and eliminate the challenges faced by them. The present study focused on the role of age and perceived teaching styles in the self-regulation of adolescents with physical disabilities in Pakistan. By studying the selfregulation of adolescents with a physical disability, teachers can be able to understand their student's strengths and weaknesses which aspects of their personality development need to work more, and how to make their students useful and independent individuals. Teachers can also understand which aspect of their development can cause complications in their personality and cause psychological problems.

\section{Study Objectives}

Following are the objectives of the study to be achieved:

1. To examine the relationship between perceived teaching style, self-regulation, long-term self-regulation, and short-term self-regulation among adolescents with a physical disability.

2. To analyze the role of the age and perceived teaching styles in the self-regulation of adolescents with physical disability in Pakistan.

3. To find out the best teaching style to improve the performance of physically disabled students.

\section{Hypotheses}

The following hypotheses are formulated:

H1: Democratic teaching styles will be the most perceived teaching style among adolescents with a physical disability

H2: There will be a positive relationship between perceived teaching style, self-regulation, long term self-regulation, and short term self-regulation among adolescents with a physical disability

H3: Perceived teaching styles will predict self-regulation significantly.

H4a: Perceived teaching styles will predict long-term self-regulation significantly.

H4b: Perceived teaching styles will predict short-term self-regulation significantly

H5: Age will moderate the relationship between perceived teaching style and self-regulation among adolescents with a physical disability.

H6: Age will moderate the relationship between authoritative teaching style and long-term self-regulation among adolescents with a physical disability.

H7: Age will moderate the relationship between democratic teaching style and short-term self-regulation among adolescents with a physical disability.

\section{METHODOLOGY}

\section{Instruments}

The Junior High School Teaching Styles Questionnaire (Chen, 2008): The 29' items questionnaire was used to get the student's perspective of perceived teaching style. The questionnaire has four sub-categories as authoritarian subscale (11 items), democratic subscale (9 items), laissez-faire subscale (5 items), and indifferent subscale (4 items). Questionnaires scored on 5-point scale, which are never $=1$, seldom $=2$, sometimes $=3$, often $=4$, and always $=5$. For negative items of scale scored as never $=5$, seldom $=4$, sometime $=3$, often $=2$, always $=1$. Higher scores on each indicate the most frequently perceived teaching style (Chen, 2008).

The Adolescent Self-Regulatory Inventory (Moilanen, 2007): The 36 items self-report questionnaire used to measure the long-term and short-term self-regulation in middle and higher school students. The questionnaires consist of short term selfregulation (13 items), long term self-regulation (14 items) when a researcher only evaluate the short term and long term selfregulation in the student. Items $1,5,7,10,24,32,33,34$, and 35 will be excluded from scoring. Participants have to respond on the 5-point scale as Not at all true for me $=1$, Not very true for $m e=2$, neither true nor untrue for $m e=3$, somewhat true for me $=4$ and really true for $m e=5$, and negative items will be scored as Not at all true for me $=5$, Not very true for me $=$ 4 , Neither true nor untrue for $m e=3$, Somewhat true for $m e=2$ and Really true for $m e=1$. 


\section{Population Sample and data Analysis}

A sample of 150 students with a physical disability, i.e. epilepsy, arthritis, polio, cerebral palsy, spinal cord injury, Spina Bifida, muscular dystrophy, and limbic amputation, were selected through the purposive-convenient sampling technique. Age ranged between 14 and 16 years from different schools of Government and the Private sector of Islamabad and Rawalpindi division. The sample included both male and female participants. Students with multiple disabilities and who cannot understand the English language were excluded from the sample. They were approached individually after the permission of school authorities, and informed consent from the participants was taken. Participants have explained the nature and purpose of the study. Questionnaires were administered, and SPSS 22 was used for data analysis.

\section{RESULTS}

Table 1: Prevalence of most perceived teaching style

\begin{tabular}{llll}
\hline Variables & $\boldsymbol{N}$ & $\boldsymbol{M}$ & $\boldsymbol{S D}$ \\
\hline Democratic TS & 150 & 40.79 & 10.97 \\
\hline Authoritarian TS & 150 & 31.64 & 8.21 \\
\hline Laissez Faire TS & 150 & 18.99 & 5.35 \\
\hline Indifferent TS & 150 & 12.96 & 5.09 \\
\hline
\end{tabular}

Source: Author Resources. TS: Teaching Style

Table 1 result showed that the democratic teaching style was the most perceived teaching style. The mean value of democratic teaching style was $40.79,31.64$ was mean of authoritarian teaching style. 18.99 and 12.96 were mean of laissezfaire and indifferent teaching style, respectively.

Table 2: Correlation between the teaching styles and self-regulation $(\mathrm{N}=150)$

\begin{tabular}{llllllllll}
\hline & Variables & M & SD & I & II & III & IV & V & V I \\
\hline 1 & Democratic TS & 40.79 & 10.97 & & & & & & \\
\hline 2 & Authoritarian TS & 31.64 & 8.21 & $.55^{* *}$ & & & & \\
\hline 3 & Lazziz faire TS & 18.99 & 5.35 & $.91^{* *}$ & $.57^{* *}$ & & & \\
\hline 4 & In different TS & 12.96 & 5.09 & .06 & $.65^{* *}$ & .14 & & \\
\hline 5 & Long term self-regulation & 42.39 & 8.28 & $.37^{* *}$ & .01 & $.39^{* *}$ & $-.22^{* *}$ & \\
\hline 6 & Short term self-regulation & 38.77 & 9.48 & .01 & $.30^{* *}$ & .05 & $.25^{* *}$ & $.32^{* *}$ & \\
\hline
\end{tabular}

Source: Author Resources

Note. **. Correlation is significant at the 0.01 level (2-tailed).

Table no 2 showed that there was a significant and positive correlation between democratic teaching style and long-term self-regulation $\left(.37^{* *}\right)$ and a negative correlation with indifferent teaching style $\left(-.22^{* *}\right)$. Short-term self-regulation had a significant and positive correlation with authoritarian $\left(.30^{* *}\right)$ and indifferent $\left(.25^{* *}\right)$ teaching style.

Table 3: Teaching Styles as Predictor of Self-Regulation of Adolescents ( $\mathrm{N}=150)$

\begin{tabular}{llllllc}
\hline Predictor & B & SE & B & t & P & 95\% CI [LL-UL] \\
\hline Constant & 65.95 & 5.17 & & 12.73 & .00 & {$[55.72-76.18]$} \\
\hline Teaching style & .14 & .04 & $.24^{* *}$ & 3.01 & .00 & {$[.05-0.24]$} \\
\hline
\end{tabular}

Source: Author Resources

Note. ${ }^{* *} \mathrm{p}<.01, * * * \mathrm{p}<.001 \mathrm{R}^{2}=.05, \Delta \mathrm{R}^{2}=.05, \mathrm{~F}=9.06 * *$

Teaching styles emerged as a significant positive predictor of adolescent self-regulation $(\beta=.24, \mathrm{t}=3.01, \mathrm{p}<.01)$. H \# 3 was supported because teaching styles appeared to be a significant positive predictor of self-regulation of the adolescent with physical disabilities and explained $9.06 \%$ of the variance in the self-regulation.

Table 4: Multiple Regression coefficient of Teaching Styles on Long-Term Self-Regulation (N=150)

\begin{tabular}{lcccccc}
\hline Predictor & B & SE & B & T & P & 95\% CI [LL-UL] \\
\hline Constant & 36.24 & 2.71 & & 13.35 & .00 & {$[30.88-41.60]$} \\
\hline Democratic TS & .008 & .14 & .01 & .05 & .95 & {$[-.28-.29]$} \\
\hline
\end{tabular}




\begin{tabular}{lcccccc}
\hline Authoritarian TS & -.13 & .13 & -.13 & -1.02 & .30 & {$[-.39-.12]$} \\
\hline Laizzes faire TS & .76 & .28 & .49 & 2.63 & .00 & {$[.18-1.33]$} \\
\hline Indifferent TS & -.33 & .17 & -.20 & -1.91 & .05 & {$[-.68-.01]$} \\
\hline
\end{tabular}

Source: Author Resources

Note. $* p<.05, * * p<.01 R^{2}=.24 * * \Delta R^{2}=.22 * *, \Delta F^{2}=11.60 * *$

The results displayed that laissez faire teaching style $(\beta=.49, \mathrm{t}=2.63, \mathrm{p}<.05)$ positively and indifferent teaching styles $(\beta=$ $-.20, \mathrm{t}=-1.91, \mathrm{p}<.05)$ negatively, were significant predictors of long-term self-regulation. $\mathrm{H} \# 4 \mathrm{a}$ was partially supported.

Table 5: Multiple Regression coefficient of Teaching Styles on Short-term Self-Regulation (N=150)

\begin{tabular}{lcccccc}
\hline Predictor & $\mathbf{B}$ & $\mathbf{S E}$ & $\mathbf{B}$ & $\mathbf{t}$ & $\mathbf{P}$ & 95\% CI [LL-UL] \\
\hline Constant & 31.33 & 3.32 & & 9.41 & .00 & {$[24.75-37.91]$} \\
\hline Democratic TS & -.30 & .18 & -.35 & -1.68 & .09 & {$[-.65-.05]$} \\
\hline Authoritarian TS & .53 & .16 & .45 & 3.29 & .00 & {$[.21-.84]$} \\
\hline Laizzes faire TS & .21 & .35 & .12 & .60 & .54 & {$[-.48-.91]$} \\
\hline Indifferent TS & -.07 & .21 & -.04 & -.36 & .71 & {$[-.50-.34]$} \\
\hline
\end{tabular}

Source: Author Resources

Note. $* * \mathrm{p}<.01, * * * \mathrm{p}<.001 \mathrm{R}^{2}=.13 * * \Delta \mathrm{R}^{2}=.10 * *, \Delta \mathrm{F}^{2}=5.45^{* *}$

The results displayed that authoritarian teaching style $(\beta=.45, \mathrm{t}=3.29, \mathrm{p}<.01)$ was significant positive predictors of shortterm self-regulation. However, democratic and laissez-faire teaching styles did not emerge as significant predictors of shortterm self-regulation among adolescents with a physical disability. $\mathrm{H}$ \# $4 \mathrm{~b}$ was partially supported because only authoritarian teaching styles appeared to be a significant positive predictor of short-term self-regulation of the adolescent with physical disabilities and explained $9.06 \%$ of the variance in the construct.

Table 6: Moderation of Age between Teaching Styles and Self-Regulation ( $\mathrm{N}=150)$

\begin{tabular}{lllllll}
\hline Variables & B & SE & t & P & \multicolumn{2}{c}{ 95\% CI [LL-UP] } \\
\hline (Constant) & 81.61 & 1.15 & 70.81 & .00 & 79.33 & 83.89 \\
\hline TS (IV) & .12 & .04 & 2.56 & .01 & .02 & .22 \\
\hline Age (Moderator) & 1.00 & 1.4 & .69 & .48 & -1.84 & 3.84 \\
\hline TS x Age (IV x Moderator) & -.16 & .06 & -2.39 & .01 & -.29 & -.02 \\
\hline
\end{tabular}

Source: Author Resources

Note. $R^{2}=.09$, TS=Teaching style, ${ }^{* *} p<.01$

Table 6 showed significant moderation of age between teaching styles and self-regulation among adolescents with special needs. The results indicated a significant change in $R^{2}(.03)$ with associated $F$ and $p$ values $\{F(4,146)=5.13, p<.01\}$. Age act as a moderator in the relationship between teaching style and self-regulation, with $9 \%$ additional variance seen in the model. H \# 5 was accepted. The interaction effect is further shown in figure 1.

Figure 1 illustrated that age act as a moderator between the teaching style and self-regulation through interconnecting lines. With the age of students, development and understanding of self-regulation was improved.

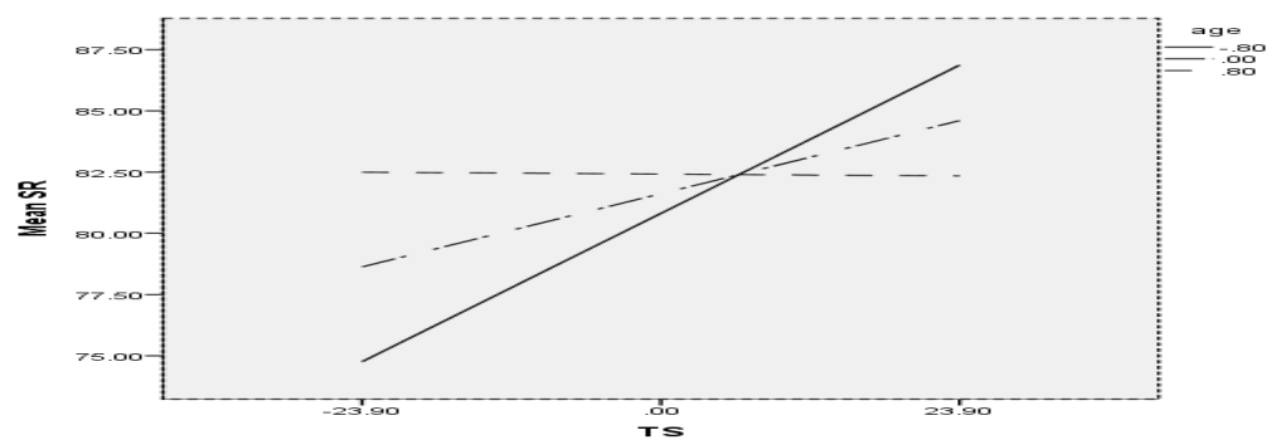

Figure 1: Moderating Role of Age on the Relationship Between Self-Regulation and Teaching Styles

Source: Author Resources 
Table 7: Moderation of Age between Authoritarian Teaching Styles and Long-Term Self-Regulation ( $\mathrm{N}=150)$

\begin{tabular}{lllllll}
\hline Variables & B & SE & t & P & 95\% CI [LL-UP] \\
\hline (Constant) & 42.52 & .65 & 64.53 & .00 & 41.21 & 43.82 \\
\hline ATS (IV) & .00 & .08 & .05 & .95 & -.15 & .16 \\
\hline Age (Moderator) & 1.37 & .82 & 1.67 & .09 & -.24 & 3.00 \\
\hline $\begin{array}{l}\text { ATS x Age } \\
\text { (IV x Moderator) }\end{array}$ & -.30 & .10 & -2.96 & .00 & -.51 & -.10 \\
\hline
\end{tabular}

Source: Author Resources

Note. $R 2=.07$, ATS $=$ Authoritarian Teaching style, ${ }^{*} \mathrm{p}<.05$

Table 7 shows significant moderation by age between the authoritarian teaching styles and long-term self-regulation of adolescents with a physical disability. The results indicated a significant change in R2 (.05) with $\mathrm{F}(4,146)=3.91, \mathrm{p}<.05$. Age acts as a moderator in the relationship between authoritarian teaching and long-term self-regulation, with $7 \%$ additional variance seen in the model. $\mathrm{H}$ \# 6 was partially supported because age moderated the relationship between only authoritarian teaching styles and long-term self-regulation. The interaction effect is further shown in figure (2).

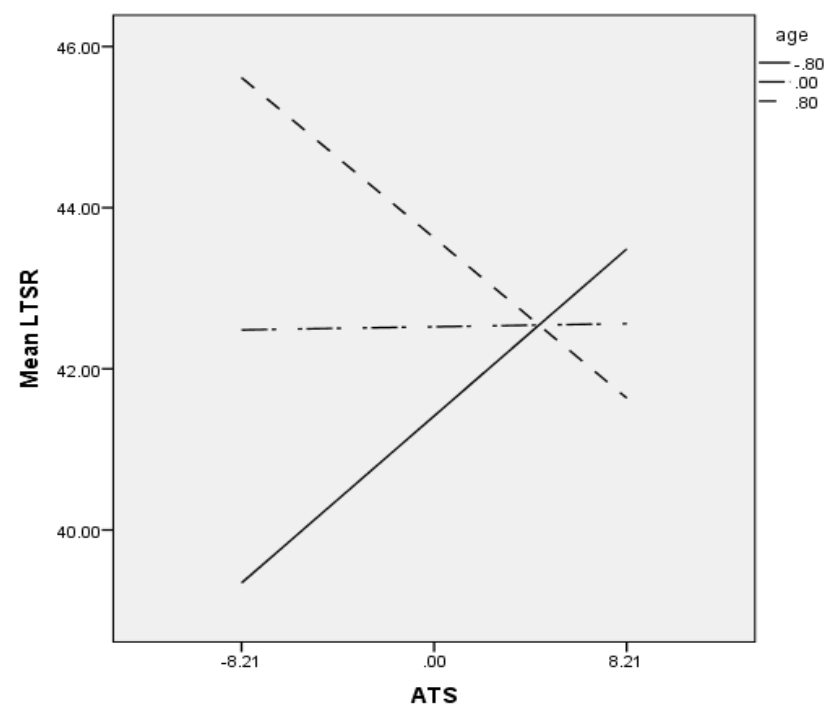

Figure 2: Moderation of Age between Authoritarian Teaching Styles and Long-Term Self-Regulation

Figure 2 illustrated that age act as a moderator between the authoritarian teaching style and long-term self-regulation through traversing lines. Student understanding about his/her self would increase with learning and age, so the relationship between authoritarian teaching styles and long self-regulation become weak and negative.

Table 8: Moderation of Age between Democratic Teaching Styles and Short-Term Self-Regulation (N=150)

\begin{tabular}{lllllll}
\hline Variables & $\mathbf{B}$ & SE & $\mathbf{t}$ & $\mathbf{p}$ & $\mathbf{9 5 \%}$ CI [LL-UP] \\
\hline (Constant) & 39.01 & .77 & 50.16 & .00 & 37.47 & 40.55 \\
\hline DTS (IV) & -.01 & .07 & -.20 & .83 & -.15 & .12 \\
\hline AGE (Moderator) & .22 & .97 & .23 & .81 & -1.69 & 2.15 \\
\hline $\begin{array}{l}\text { DTS x AGE } \\
\text { (IV x Moderator) }\end{array}$ & -.20 & .09 & -2.18 & .03 & -.39 & -.01 \\
\hline
\end{tabular}

Note. $R 2=.03, \mathrm{DTS}=$ Democratic Teaching style, ${ }^{*} \mathrm{p}<.05$

Table 8 showed significant moderation by age between the democratic teaching styles and short-term self-regulation of adolescents with a physical disability. The results indicated a significant change in $\mathrm{R}^{2}(.03)$ with $\mathrm{F}(4,146)=1.59, \mathrm{p}<.05$. The age acts as a moderator in the relationship between democratic teaching and short-term self-regulation, with 3\% additional variance seen in the model. $\mathrm{H}$ \# 7 was partially supported because age moderated the relationship between only democratic teaching styles and short-term self-regulation. The interaction effect is further shown in figure (3). 


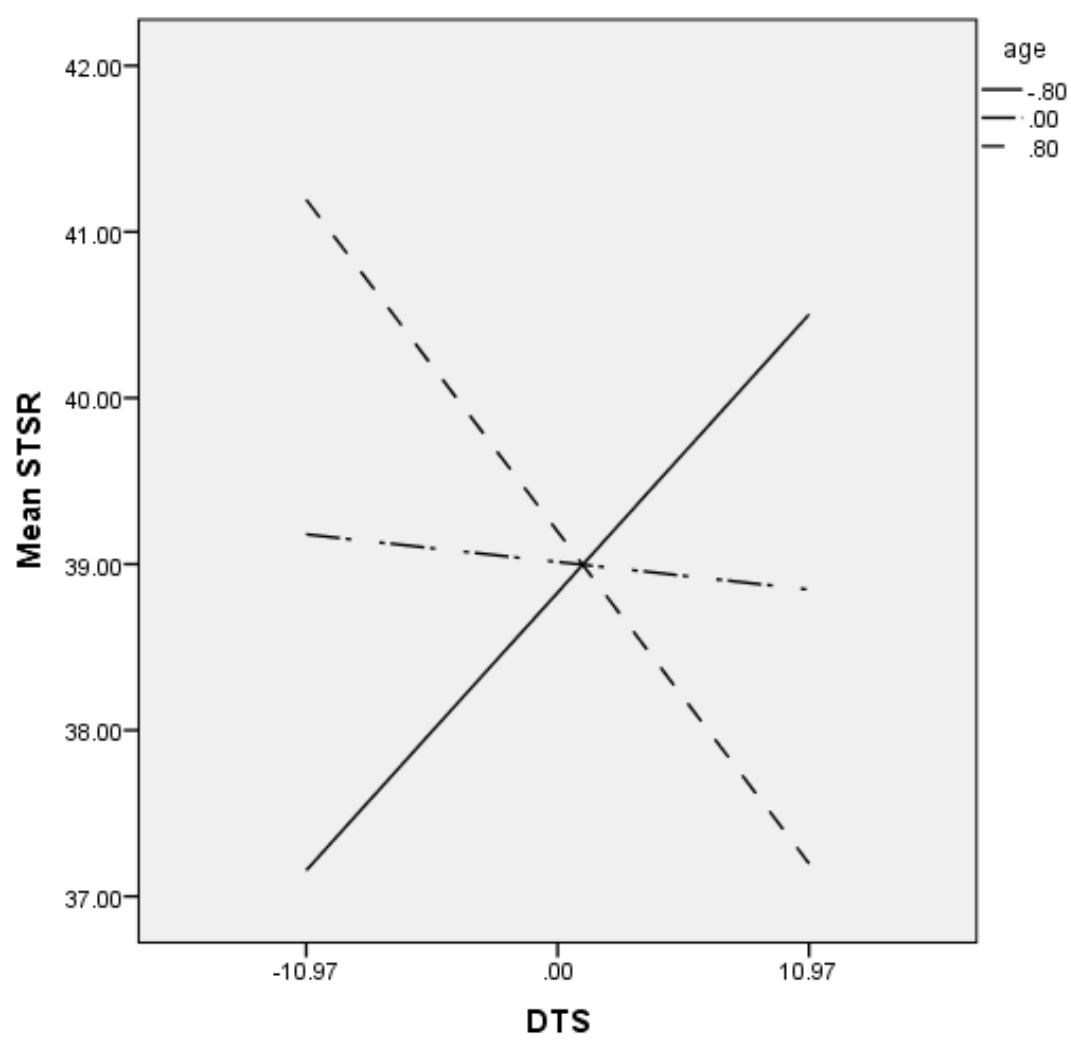

Figure 3: Moderation of Age between Democratic Teaching Styles and Short-Term Self-Regulation

Figure3 illustrated that age acts as a moderator between democratic teaching and short-term self-regulation through traversing lines. When with age learning and understanding of the adolescent improved, then democratic teaching styles are used to develop short self-regulation.

\section{DISCUSSION}

Finding revealed that the democratic teaching style was the most perceived teaching style of adolescents with a physical disability. The mean value of the democratic teaching style is 40.79 , while 31.64 is the mean of the authoritarian teaching style. 18.99 and 12.96 are mean of laissez-faire and indifferent teaching style, respectively. New trends of teaching are adopted in our schools. Students like the democratic teaching style because, with this style, they have a flexible attitude and understand the exclusive needs of learners. Teachers can encourage their students to actively participate in and outside class activities. The democratic teaching style perceived as a teaching style by students in general public schools, and followers of this style showed good results. Students can learn and perform better when their instructors are employed involving an interactive teaching style, e.g., democratic teaching style for them as compared to those instructors who prefer a conventional teaching style (Chen, 2008, Munir \& Rehman, 2016).

Moreover, a positive relationship between perceived teaching styles and self-regulation in adolescents with physical disabilities has been found. Teaching styles appears to be a significant positive predictor of self-regulation of the adolescent with physical disabilities because teacher behaviour and attitude have a strong impact on the student with special needs. They are dependent on their teachers, so the teacher's harsh attitude has a negative impact on them. They expect favourable behaviour from their teachers, so teacher's strict attitude has a negative impact on them. For teachers, it is important to be aware of the self-regulation process in a way to focus on the child's ability to attain and sustain the required behaviour and energy for any specific task. Modify and control one emotions and attention according to the situation and relate to the situation and understand other feelings.

Students with good self-regulation are actively engaged in the learning process because it has a strong effect on their motivation, meta-cognition, and actions. Decision-making was also affected as intact self-regulation associates with spontaneous and rational decision-making, while impaired self-regulation demonstrates a style of avoidance and conditional decision-making. (Hayee, 2009; Bonnett \& Maich, 2014, Mega, Ronconi, \& DeBeni, 2014).

The finding indicated that laisse fair teaching styles are significant positive predictors of long-term self-regulation as in these styles' teachers have a caring, gentle and flexible attitude towards students, and they encourage the student in the process of 
teaching and learning. On the other hand, authoritarian teaching styles is a negative predictor of long-term self-regulation because teacher harsh and strict attitude or negative remarks are the reason of losing their interest in studies and planning for future or achievement of goals. The findings are consistent with others (Coetzee \& Jansen, 2007, Fergus \& Zimmerman, 2005, Bishep, 2006, Hoylee, 2006). Successful teachers agree that only when they are emotionally secure and feel relaxed and supportive in the classroom setting will students perform better. Children need to be motivated to build healthy social interaction and a sense of self-esteem; even if they face rejection or bullying, it will help to control them for target accomplishment. Children are unable to cope with other people's negative actions, especially rejection by friends due to poor skills in self-regularity. They were not able to gain social and emotional security. To resolve moderate psychopathologies, they are unable to enjoy psychological wellbeing and lose control.

The authoritarian teaching style is a significant positive predictor of short-term self-regulation because sometimes strictness and firmness are required to explain to students how to control the instinct of immediate gratification and about moral values and social taboo and norms. Mcclelland and Cameron (2010) endorsed these findings, which found an important relationship with their teaching strategies between self-regulation of students and emotional strategies. Teachers having an authoritarian teaching style sets class rules and specify a consequence for violation of these rules, and showed strict behaviour in class (Chen, 2008). Furthermore, many researchers indicated a negative association between student-teacher conflicts and students' behavioural issues of self-regulation, effortful inhibition, and control over discipline and attention (e.g., Berry, 2012; Hamre \& Pianta, 2001; Ladd \& Burgess, 2001).

Additionally, age played the role of a significant moderator in the relationship between teaching style and self-regulation among adolescents with a physical disability. With time, our level of understanding and learning is increased, which enhances student self-regulation and their relationship with teachers. It was backed by results from Blair \& Razza (2007). Findings suggest that ties between emotional control and learning capacity are more moderate to strong because the skills gained are more effortful, based on the higher demand for emotional skills of students. The use of maximum self-regulatory actions relies on memory, persistence, and thinking skills for the learning process (

Age also acted as a significant moderator in the relationship between authoritarian teaching style and long-term selfregulation among adolescents with a physical disability. Student understanding of his/her self would be increased with learning and age, so the relationship between authoritarian teaching styles and long self-regulation become weak and negative. When student understanding increases, then the strict attitude of teachers is no longer required. It was in harmony with the finding of Daniels and Perry (2003). For the formation of greater enthusiasm in student's teachers should use more learner-centred strategies; teachers involve their students in decision making, understanding their differences in personal, developmental, and relational needs.

Age played the role of moderator between democratic teaching style and short-term self-regulation among adolescents with a physical disability. As the previous finding revealed that for impulse control (training of student short term self-regulation) strict attitude and firm rule are required from teachers, but now students are grown and understanding social taboo and moral standards, so no more strictness is needed. As cited by Khandaghi (2011), teachers are responsible not only for cognitive and mental development but they should be vigilant about emotional, social, and spiritual wellbeing and progress. Rosenfeld et al. (2000) revealed that kind, warm, helpful teachers create motivation and inspiration to participate in the learning process, built emotional and cognitive success in students. Because teachers have good interactions with their pupils, the conduct of students in relation to school is influenced. Students who regard their teachers as highly kind have fewer behavioural issues and more regular and observed.

\section{CONCLUSION}

In the present research, democratic teaching style was most perceived teaching style among the adolescent with a physical disability. Democratic teaching style had a significant relationship with long-term self-regulation. Meanwhile, authoritarian teaching style had significant relation with self-regulation (short-term). Additionally, significant moderation of age on the relationship of teaching style and self-regulation of an adolescent with a physical disability was found. These findings suggest that teaching style and self-regulation are important and should be encouraged in school to improve the performance of adolescents with a physical disability. With age and the development of self-regulation, the disabled student became a useful and practical citizen of society. Therefore, this information will be beneficial for teachers, school counselors, parents, and other stakeholders.

\section{LIMITATIONS \& FUTURE DIRECTIONS}

More teaching styles should be explored in the future better to appreciate their effect on students with physical disabilities other than democratic style. These variables should be studies with other disabilities ie visual and hearing impairment. Other demographic variables can provide more significant information. 


\section{ACKNOWLEDGEMENT}

We would like to thank all the independent reviewers of HSSR who conducted a feasibility study of our research work.

\section{AUTHORS CONTRIBUTION}

Touseef Khalid, Dr. Iffat Rohail contributed to writing the research and designing the organization of the article. Andleeb Akhtar perform the statistical analyses, interpretations, and technical parts. All the author(s) have a significant contribution to the research article.

\section{REFERENCES}

1. Alhussain, A. M. (2012). Identifying Teaching Style: The Case of Saudi College English Language and Literature Teachers. English Language Teaching, 5(8), 122-129. https://doi.org/10.5539/elt.v5n8p122

2. Baker, J. A. (2006). Contributions of teacher-child relationships to positive school adjustment during elementary school. Journal of school psychology, 44(3), 211-229. https://doi.org/10.1016/j.jsp.2006.02.002

3. Baumeister, R. F., \& Bushman, B. J. (2008). Social psychology and human nature (Annotated instructor's ed.). Thomson Wadsworth.

4. Baumeister, R. F., Vohs, K. D., \& Tice, D. M. (2007). The strength model of self-control. Current directions in psychological science, 16(6), 351-355. https://doi.org/10.1111/j.1467-8721.2007.00534.x

5. Berry, D. (2012). Inhibitory control and teacher-child conflict: Reciprocal associations across the elementary-school years. Journal of Applied Developmental Psychology, 33(1), 66-76. https://doi.org/10.1016/j.appdev.2011.10.002

6. Bishop, J. (2006). Drinking from the fountain of knowledge: Student incentive to study and learn-externalities, information problems and peer pressure. Handbook of the Economics of Education, 2, 909-944. https://doi.org/10.1016/S1574-0692(06)02015-0

7. Blair, C., \& Razza, R. P. (2007). Relating effortful control, executive function, and false belief understanding to emerging math and literacy ability in kindergarten. Child Development, 78(2), 647-663. https://doi.org/10.1111/j.1467-8624.2007.01019.x

8. Bonnett, T., \& Maich, K. (2014). The foundational "R". Canadian Education Association, 54(3). Retrieved from http://www.cea-ace.ca/educationcanada/article/foundational-"r"

9. Cadima, J., Doumen, S., Verschueren, K., \& Buyse, E. (2015). Child engagement in the transition to school: Contributions of self-regulation, teacher-child relationships and classroom climate. Early Childhood Research Quarterly, 32, 1-12. https://doi.org/10.1016/j.ecresq.2015.01.008

10. Callan, G. L., \& Cleary, T. J. (2018). Multidimensional assessment of self-regulated learning with middle school math students. School Psychology Quarterly, 33(1), 103. https://doi.org/10.1037/spq0000198

11. Chang, Y. C. (2010). Students' perceptions of teaching styles and use of learning strategies. Unpublished master's thesis, University of Tennessee, Knoxville.

12. Chen, Y. C. (2008). An investigation of the relationships between teaching style and studies achievement in Miaoli Jianguo Junior High School. Unpublished master's thesis. Hsuan Chuang University, Miaoli, Taiwan.

13. Coetzee, M., \& Jansen, C. (2007). Emotional intelligence in the classroom. The Secret of Happy Teachers. Cape Town: Juta.

14. Conti, G.J. (2004). Identifying your teaching style. In M.W. Galbraith (Ed.), Adult Learning Methods: A Guide for Effective Instruction (3rd ed., pp. 7591). FL: Krieger Publishing Company

15. Daniela, (2005). The relationship between self-regulation, motivation and performance at secondary school students. Procedia-Social and Behavioral Sciences, 191, 2549-2553. https://doi.org/10.1016/j.sbspro.2015.04.410

16. Daniels, D. H., \& Perry, K. E. (2003). " Learner-centered" according to children. Theory into Practice, 42(2), $102-$ 108. https://doi.org/10.1353/tip.2003.0012

17. de la Fuente, J., Martínez-Vicente, J. M., Peralta-Sánchez, F. J., González-Torres, M. C., Artuch, R., \& GarzónUmerenkova, A. (2018). Satisfaction With the Self-Assessment of University Students Through e-Coping With Academic Stress UtilityTM. Frontiers in psychology, 9, 1932. https://doi.org/10.3389/fpsyg.2018.01932

18. de la Fuente, J., Peralta-Sánchez, F. J., Martínez-Vicente, J. M., Sander, P., Garzón-Umerenkova, A., \& Zapata, L. (2020). Effects of Self-Regulation vs. External Regulation on the Factors and Symptoms of Academic Stress in Undergraduate Students. Frontiers in Psychology, 11. https://doi.org/10.3389/fpsyg.2020.01773

19. Demetriou, A., Kui, Z. X., Spanoudis, G., Christou, C., Kyriakides, L., \& Platsidou, M. (2005). The architecture, dynamics, and development of mental processing: Greek, Chinese, or Universal? Intelligence, 33(2), 109-141. https://doi.org/10.1016/j.intell.2004.10.003

20. Elsevier, A. R. (2012). Effects of teaching and learning styles on students' reflection levels for ubiquitous learning. Retrieved August 28, 2012, from http://lcell.bnu. edu.cn/cankaowenxian/foreign/Effect_of teaching_andlearning _styles_on_students_reflection_levels_for_ubiquitous_learning 
21. Fergus, S., \& Zimmerman, M. A. (2005). Adolescent resilience: A framework for understanding healthy development in the face of risk. Annu. Rev. Public Health, 26, 399-419. https://doi.org/10.1146/annu rev.publhealth.26.021304.144357

22. Fomina, T., Burmistrova-Savenkova, A., \& Morosanova, V. (2020). Self-regulation and psychological wellbeing in early adolescence: A two-wave longitudinal study. Behavioral Sciences, 10(3), 67. https://doi.org/10.33 90/bs10030067

23. Genc, E., \& Ogan-Bekiroglu, F. (2004). Patterns in Teaching Styles of Science Teachers in Florida and Factors Influencing Their Preferences. Online Submission.

24. Gupta, S., \& Bashir, L. (2017). Educational Aspiration of Secondary School Students: Influence of School Environment and Parental Encouragement. International Journal of Applied Business and Economic Research, 15(21), 495-507.

25. Hamre, B. K., \& Pianta, R. C. (2001). Early teacher-child relationships and the trajectory of children's school outcomes through eighth grade. Child Development, 72,625-638. http://dx.doi.org/10.1111/1467-8624.00301

26. Hayee, A. A. (2009). Self-Regulation as predictor of decision making styles. M.Sc. Unpublished Dissertation. National institute of Psychology, Quaid-i-Azam University, Islamabad.

27. Hoyle, R. H. (2006). Personality and self-regulation: Trait and information-processing perspectives. Journal of Personality, 74(6), 1507-1526. https://doi.org/10.1111/j.1467-6494.2006.00418.x

28. Hussain, N., \& Ayub, N. (2012). Learning styles of students and teaching styles of teachers in business education: A case study of Pakistan. Procedia-Social and Behavioral Sciences, 69, 1737-1740. https://doi.org/10.1016/ j.sbspro.2012.12.122

29. Khandaghi, M. A., \& Farasat, M. (2011). The effect of teacher's teaching style on students' adjustment. ProcediaSocial and Behavioral Sciences, 15, 1391-1394. https://doi.org/10.1016/j.sbspro.2011.03.299

30. Ladd, G. W., \& Burgess, K. B. (2001). Do relational risks and protective factors moderate the linkages between childhood aggression and early psychological and school adjustment? Child Development, 72(5), 1579-1601. https://doi.org/10.1111/1467-8624.00366

31. Lage, M. J., Platt, G. J., \& Treglia, M. (2000). Inverting the classroom: A gateway to creating an inclusive learning environment. The journal of economic education, 31(1), 30-43. https://doi.org/10.2307/1183338

32. Mamta, K., \& Ahmad, W. (2020). Developing Social Skills among Individuals with Intellectual Disability using Positive Behavior Intervention and Support. Journal of Psychosocial Research, 15(2).

33. McClelland, M. M., Ponitz, C. C., Messersmith, E. E., \& Tominey, S. (2010). Self-regulation: Integration of cognition and emotion. The handbook of life-span development. https://doi.org/10.1002/978 0470880166.hlsd001015

34. McTigue, E. M., Barrois, L., \& Hughes, J. N. (2008). Adaptive and effortful control and academic self-efficacy beliefs on achievement: A longitudinal study of 1st through 3rd graders. Early childhood research quarterly, 23(4), 515-526. https://doi.org/10.1016/j.ecresq.2008.07.003

35. Mega, C., Ronconi, L., \& De Beni, R. (2014). What makes a good student? How emotions, self-regulated learning, and motivation contribute to academic achievement. Journal of Educational Psychology, 106(1), 121. https://doi.org/10.1037/a0033546

36. Miller, D. C., \& Byrnes, J. P. (2001). Adolescents' decision making in social situations: A self-regulation perspective. Journal of Applied Developmental Psychology, 22(3), 237-256. https://doi.org/10.1016/S01933973(01)00082-X

37. Moilanen, K. L. (2007). The adolescent self-regulatory inventory: The development and validation of a questionnaire of short-term and long-term self-regulation. Journal of youth and adolescence, 36(6), 835-848. https://doi.org/10.1007/s10964-006-9107-9

38. Munir, F., \& Rehman, A. U. (2016). Most frequent Teaching Styles and Students' Learning Strategies in Public High Schools of Lahore Pakistan. Science International Lahore, 28(2), 1669-1674

39. Murray, D. W., \& Rosanbalm, K. (2017). Promoting Self-Regulation in Adolescents and Young Adults: A Practice Brief. OPRE Report 2015-82. Office of Planning, Research and Evaluation.

40. Neeraj, N., \& Ahluwalia, P. S. (2020). Physical Activity, Self-Esteem and Body Composition among Male College Teachers. European Journal of Physical Education and Sport Science, 6(5), 109-121

41. Novak, S. P., \& Clayton, R. R. (2001). The influence of school environment and self-regulation on transitions between stages of cigarette smoking: A multilevel analysis. Health Psychology, 20(3), 196. https://doi.org/10.1037/0278-6133.20.3.196

42. Opdenakker, M. C., \& Van Damme, J. (2006). Teacher characteristics and teaching styles as effectiveness enhancing factors of classroom practice. Teaching and Teacher Education, 22(1), 1-21. https://doi.or g/10.1016/j.tate.2005.07.008 
43. Pachler, D., Kuonath, A., Specht, J., Kennecke, S., Agthe, M., \& Frey, D. (2018). Workflow interruptions and employee work outcomes: The moderating role of polychronicity. Journal of Occupational Health Psychology, 23(3), 417. https://doi.org/10.1037/ocp0000094

44. Paris, S.G., \& Winograd, P. (2003). The role of self-regulated learning in contextual teaching: Principles for teacher preparation. A. Commissioned Paper for the U.S. Department of Education project, "Preparing Teachers to Use Contextual Teaching and Learning Strategies to Improve Student Success in and beyond School.", Washington, DC.

45. Patock-Peckham, J. A., Cheong, J., Balhorn, M. E., \& Nagoshi, C. T. (2001). A social learning perspective: a model of parenting styles, self-regulation, perceived drinking control, and alcohol use and problems. Alcoholism: Clinical and Experimental Research, 25(9), 1284-1292. https://doi.org/10.1111/j.1530-0277.2001.tb02349.x

46. Peacock, J., Chur-Hansen, A., \& Winefield, H. (2012). Mental health implications of human attachment to companion animals. Journal of Clinical Psychology, 68(3), 292-303. https://doi.org/10.1002/jclp.20866

47. Pianta, R. C. (1999). Enhancing relationships between children and teachers. American Psychological Association. https://doi.org/10.1037/10314-000

48. Putwain, D. W., Gallard, D., \& Beaumont, J. (2019). A multi-component wellbeing programme for upper secondary students: Effects on wellbeing, buoyancy, and adaptability. School Psychology International, 40(1), 49-65. https://doi.org/10.1177/0143034318806546

49. Ray, K., \& Smith, M. C. (2010). The kindergarten child: What teachers and administrators need to know to promote academic success in all children. Early Childhood Education Journal, 38(1), 5-18. https://doi.org/10.1007/s10643010-0383-3

50. Rosenfeld, L. B., Richman, J. M., \& Bowen, G. L. (2000). Social support networks and school outcomes: The centrality of the teacher. Child \& Adolescent Social Work Journal, 17(3), 205-226. https://doi.org/10.10 23/A:1007535930286

51. Rudasill, K. M., \& Rimm-Kaufman, S. E. (2009). Teacher-child relationship quality: The roles of child temperament and teacher-child interactions. Early Childhood Research Quarterly, 24(2), 107-120. https://doi.org/10.1016/j.ecresq.2008.12.003

52. Shannon, S., Hanna, D., Haughey, T., Leavey, G., McGeown, C., \& Breslin, G. (2019). Effects of a mental health intervention in athletes: Applying self-determination theory. Frontiers in Psychology, 10, 1875. https://doi.org 110.3389/fpsyg.2019.01875

53. Sharma, S., Bansal, R., Parashar, P., Ahmad, S., Kumar, A., \& Kumar, A. (2020). Stress and Depression Among People Admitted in a COVID 19 Quarantine Centre of North India. Subharti J Interdiscip Res, 3.

54. Umer, S., \& Siddiqui, J. A. (2013). Improving trends of teaching methods used in the concept schools of Karachi: An Evaluative study. Educational Research International, 2(2), 146-154.

55. Vermunt, J. D., \& Verloop, N. (1999). Congruence and friction between learning and teaching. Learning and Instruction, 9(3), 257-280. https://doi.org/10.1016/S0959-4752(98)00028-0

56. Wayment, H. A., \& Cavolo, K. (2019). Quiet ego, self-regulatory skills, and perceived stress in college students. Journal of American College Health, 67(2), 92-96. https://doi.org/10.1080/07448481.2018.1462826

57. Zhao, L., \& Chen, X. (2016, August). Analysis on the relationship between teaching style and teaching performance of College Teachers. In 2016 International Conference on Humanity, Education and Social Science (pp. 460-463). Atlantis Press. https://doi.org/10.2991/ichess-16.2016.99

58. Zheng, W., Huang, Y., \& Fu, Y. (2020). Mediating effects of psychological resilience on life satisfaction among older adults: A cross-sectional study in China. Health \& Social Care in the Community, 28(4), 1323-1332. https://doi.org/10.1111/hsc.12965

59. Zimmerman, B.J \& Kitsantas, A. (2005). A. The hidden dimension of personal competence: Self-regulated learning and Practice. In A.J. Elliot, \& C.S. Dweck (Eds.), Handbook of Competence and Motivation (pp.509-526). The Guilford Press: New York. 